\title{
Regulation of phytoplankton biomass in estuarine enclosures*
}

\author{
Bo Riemann**, Torkel Gissel Nielsen***, Steen Jesper Horsted ${ }^{* * *}$, Peter Koefoed \\ Bjørnsen***, Jan Pock-Steen
}

Freshwater Biological Laboratory, University of Copenhagen, Helsingersgade 51, DK-3400 Hillerød, Denmark

\begin{abstract}
During April, June/July and September 1986, phytoplankton biomass was followed in marine enclosures in the Roskilde Fjord, Denmark, manipulated by the addition of benthic suspension feeders, planktivorous fish, nutrients and contact to the sediment. During periods with high insolation and temperatures from 11 to $22^{\circ} \mathrm{C}$, the manipulations caused marked changes in the development of phytoplankton biomass. Additions of Mytilus edulis reduced phytoplankton biomass to between 10 and $59 \%$ of controls, whereas addition of nutrients raised phytoplankton biomass to an average of $256 \%$ of controls. Generally, low growth rates of mussels were found in enclosures containing mussels alone. Addition of planktivorous fish and nutrients increased growth rates of mussels. During June/July, when inorganic nitrogen limited phytoplankton growth, autotrophic picoplankton ( 1 to $2 \mu \mathrm{m}$ cell diameter) constituted 70 to $93 \%$ of phytoplankton biovolume in enclosures containing mussels compared to 4 to $20 \%$ in controls. The mussels reduced phytoplankton biomass by only about $50 \%$ during this period, presumably due to low retention efficiency of the small cells. In April and September, however, when nitrogen did not control phytoplankton growth, picoplankton comprised $<0.001 \%$ of phytoplankton biovolume. During September (temperatures 11 to $13^{\circ} \mathrm{C}, \mathrm{M}$. edulis reduced chlorophyll levels to $10 \%$ of controls and the effects of nutrient additions were significantly reduced in enclosures containing mussels. The effect of fish additions revealed that zooplankton grazing removed (average for June and September) about $20 \%$ of phytoplankton biomass. The sediment acted primarily as a nutrient source during summer. However, in April at temperatures $>6{ }^{\circ} \mathrm{C}$ and in September, benthic suspension feeders maintained chlorophyll levels below those in enclosures with no sediment contact. During April, only minor changes were recorded in the chlorophyll levels in the various enclosures, presumably due to the low temperature $\left(0\right.$ to $\left.4.5^{\circ} \mathrm{C}\right)$ and a phytoplankton population of decaying diatoms. Thus, several factors or combinations of factors controlled the phytoplankton biomass in the enclosures. The most important of these factors was the balance between nutrient input, phytoplankton size structure and the physiological state of the mussels.
\end{abstract}

\section{INTRODUCTION}

Eutrophication in estuaries and fjords often leads to an increase in phytoplankton primary production and biomass (Boynton et al. 1982, Nixon \& Pilson 1983), at the expense of macrophyte communities (Cattaneo \& Kalff 1980, Borum 1983). These changes are recorded

- Contribution No, 479 from the Freshwater Biological Laboratory

Present addresses:

- The International Agency for ${ }^{14} \mathrm{C}$ Determination, The Water Quality Institute, Agern Allé 15, DK-2970 Horsholm, Denmark

-. Marine Biological Laboratory, University of Copenhagen, DK-3000 Helsinger, Denmark

-.. Danish Institute for Fisheries and Marine Research, Charlottenlund Castle, DK-2920 Charlottenlund, Denmark mainly through descriptions of isolated organisms or through detailed studies of the phosphorus and nitrogen cycle (Nixon \& Pilson 1983). Such studies, however, reveal little with regard to other mechanisms controlling phytoplankton such as zooplankton and benthic suspension feeders.

Studies have been carried out on the growth of benthic suspension feeders (e.g. Fréchette \& Bourget 1985a), and Cloern (1982) and Officer et al. (1982) discussed the ecological importance of benthic suspension feeders in mitigating eutrophication trends. Most of these studies evaluate the importance of benthic communities on the basis of potential clearance rates determined in vitro (Mohlenberg \& Riisgård 1979, Jørgensen 1984). Results from such calculations, however, cannot be used to predict natural ecological events, since few, if any, environmental 
factors (i. e. actual food concentrations; food quality) are considered. Kautsky (1981) discussed the ecological role of a Mytilus edulis community on the basis of short-time measurements of nutrient-release in small enclosures. About $30 \%$ of the phytoplankton primary production was channeled through the $M$. edulis community. For a number of reasons, Kautsky asserted that the $M$. edulis beds acted as a stabilizing factor in the ecosystem but, again, the calculated clearance rates of the $M$. edulis community were based on results from laboratory experiments neglecting, for example, that $M$. edulis communities may be food limited during some periods (Fréchette \& Bourget 1985b).

The objective of this study was to evaluate the potential roles of Mytilus edulis filtration, predation by zooplankton (by additions of planktivorous fish), effects of contact with the sediment, and nutrients addition on the biomass of phytoplankton. During 3 periods, representing temperature regimes from 0 to $22^{\circ} \mathrm{C}$, large plastic enclosures containing water from Roskilde Fjord were incubated with nutrients, benthic suspension feeders and planktivorous fish, with or without contact to the sediment.

\section{MATERIALS AND METHODS}

Enclosure experiments were carried out during spring (5 to 28 April), summer (17 June to 3 July), and autumn ( 8 to 25 September) 1986, in the eutrophic estuary Roskilde Fjord near the city of Frederikssund, Denmark. At the start of each experiment, water from the estuary was filled into 24 clear cylindrical plastic enclosures (ca $3.5 \mathrm{~m}$ deep, $1.5 \mathrm{~m}$ in diameter with $0.1 \mathrm{~mm}$ thick walls). The enclosures were fixed to a pontoon bridge situated about $200 \mathrm{~m}$ from shore. Eight of the enclosures were in contact with the sediment and 16 were closed (Fig. 1).

Enclosure manipulations. Nutrients, nitrate and phosphate (spring period) or nitrate alone (summer and autumn periods), were added on each sampling day to avoid nutrient depletion. Amounts added were $0.67 \mathrm{~g}$ $\mathrm{NO}_{3}-\mathrm{N}$ per enclosure, corresponding to a final concen-

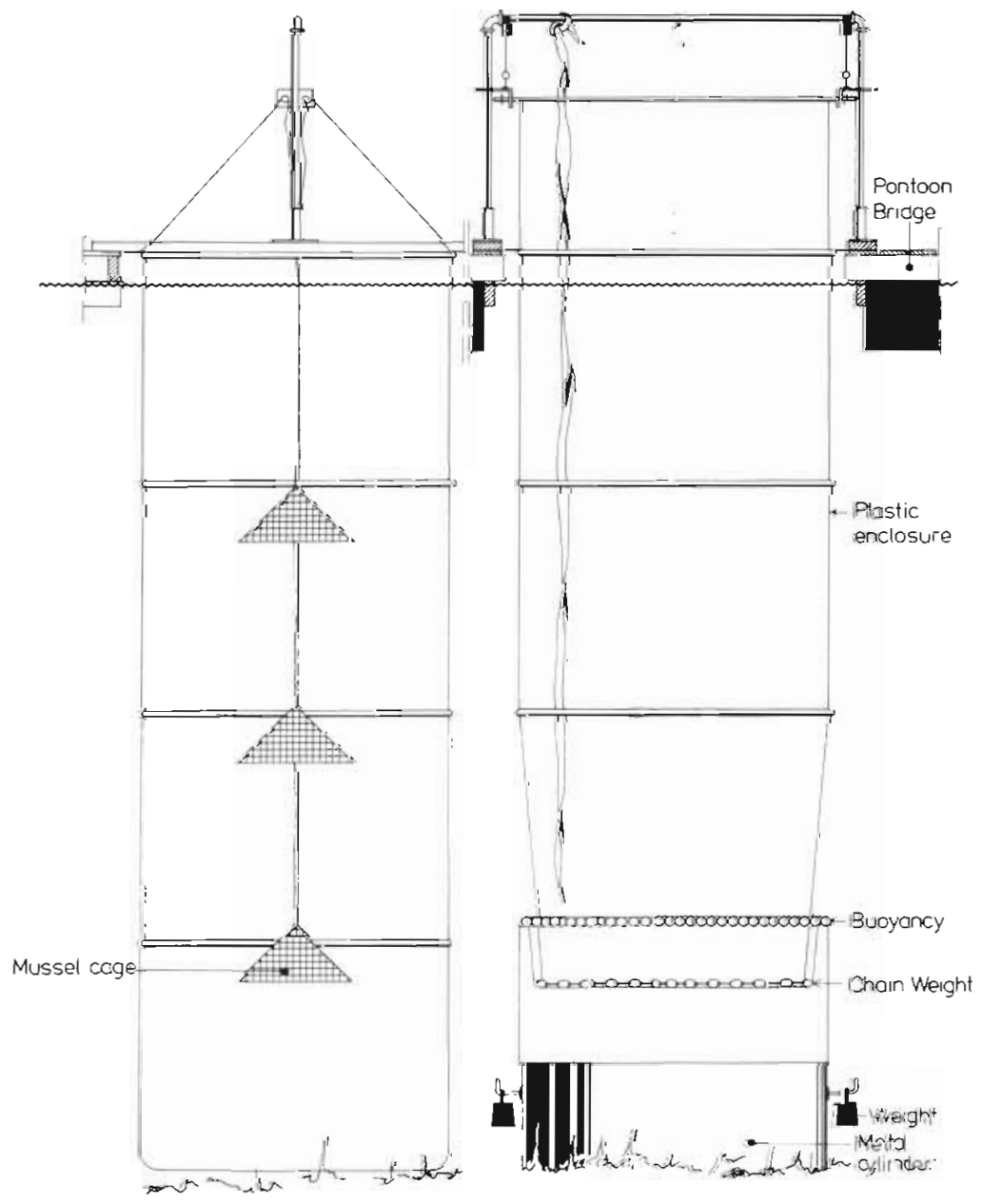

Fig. 1. Closed enclosure with mussel cages added and open enclosure (open with contact to the sediment) with the buoyancy and weight system to compensate for changes in the water level 
tration of about $112 \mu \mathrm{g} \mathrm{NO}-\mathrm{N} \mathrm{I}^{-1}$, and $0.1 \mathrm{~g} \mathrm{PO}_{4}-\mathrm{P}$ per enclosure, corresponding to a final concentration of about $17 \mu \mathrm{g} \mathrm{PO}_{4} \mathrm{l}^{-1}$. These additions equalled expected nitrate and phosphate consumption rates calculated from measurements of primary production in Roskilde Fjord (L. M. Jensen et al. unpubl.).

Fish additions were of three-spined sticklebacks Gasterosteus aculeatus at densities of $10 \mathrm{~g}$ wet wt per enclosure (ca $5.7 \mathrm{~g}$ wet $\mathrm{wt} \mathrm{m}^{-2}$ ), corresponding to 20 to $35,1^{+}$fish (1 yr old) of average weight 0.3 to $0.5 \mathrm{~g}$ wet wt. Natural populations of planktivorous fish in Roskilde Fjord are dominated by three-spined and ninespined stickleback Pungitius pungitius with an average biomass of ca $5 \mathrm{~g}$ wet wt $\mathrm{m}^{-2}$ (Gislason 1980). As the three-spined stickleback is the more common species, it was used exclusively in the experiments. The fish were cought in Roskilde Fjord a few days prior to the experiments and acclimated in situ in nets until used.

Mussels were added in amounts chosen by the following reasoning. The mean wet weights of suspension-feeding bivalves were calculated from 30 bottom samples taken with a Haps bottom sampler in Roskilde Fjord prior to each experiment. $M$. edulis constituted $323 \mathrm{~g} \mathrm{~m}^{-2}$, Mya arenaria $52 \mathrm{~g} \mathrm{~m}^{-2}$ and Cardium edule $56 \mathrm{~g} \mathrm{~m}^{-2}$, giving a total of $431 \mathrm{~g}$ wet $w \mathrm{~m}^{-2}$; a value almost identical to the $400 \mathrm{~g}$ wet wt $\mathrm{m}^{-2}$ reported by Gislason (1980). From the size distribution of the bivalve population in Roskilde Fjord, the average filtration rate $\mathrm{m}^{-2}$ was calculated from the relation between length and dry weight of the tissue (Winter 1973), while the conversion to filtration was made according to values from Møhlenberg \& Riisgaard (1979). An average potential filtration $\mathrm{m}^{-2}$ of about $7 \mathrm{~m}^{3} \mathrm{~d}^{-1}$ of the natural bivalve population was converted to filtration of $18 \mathrm{~mm}$ long $M$. edulis, and corresponded to $195 \mathrm{~g}$ wet wt $\mathrm{m}^{-2}$. Mussels of equal size (15 to $22 \mathrm{~mm}$ ) were used in order to facilitate assessment of growth during the experiments. The length of $18 \mathrm{~mm}$ was chosen for the following reasons: (1) $M$. edulis maintain maximal net growth efficiencies at least up to body weights of about $100 \mathrm{mg}$ dry wt (corresponding to a size $<18 \mathrm{~mm}$ ) (Jørgensen 1976); (2) growth experiments conducted in the Limfjord, Denmark, using $M$. edulis of shell length 15 to $30 \mathrm{~mm}$, resulted in up to a 4 -fold biomass increase over 14 to $18 d$ (Riisgaard \& Poulsen 1981); and (3) $M$. edulis from the sampling locality should not be sexually mature at these lengths (N. Svennevig pers. comm.). In fact, we did not observe spawning. The above conversion resulted in the addition of $345 \mathrm{~g}$ wet wt of $18 \mathrm{~mm}$ $M$. edulis per enclosure in spring and summer and $237 \mathrm{~g}$ wet wt per enclosure in autumn. During spring and summer mussels were sampled from a mussel farm, The Isefjord Group, in the nearby Isefjord. The Isefjord Group was closed prior to the September experiment, and mussels were therefore collected from the cooling system of the Kyndby power plant in Isefjord. The population here was sparse, which accounts for the smaller additions which therefore had to be used in the enclosures.

Prior to each experiment mussels were sorted and individuals of 15 to $22 \mathrm{~mm}$ were acclimated to the ambient conditions in a well-box 4 to $5 \mathrm{~d}$ before setting up the enclosures. Before mussels were added to the enclosures a subsample of 600 individuals was taken, and maximum anterior-posterior dimension, individual dry weight and content of organic matter were measured. The mussels were distributed among 3 cages (Japanese pearl nets of $4.5 \mathrm{~mm}$ mesh) suspended in the center of the enclosures at 1,2 , and $3 \mathrm{~m}$ depths. Between 110 and 200 individuals (15 to $22 \mathrm{~mm}$ in length) were placed in each cage. To measure growth of mussels in the open fjord, 2 sets of 3 pearl nets were placed at the same depths outside the enclosures. At the end of the experiments shell length was measured on all individuals, while dry weight $\left(2 \mathrm{~d}\right.$ at $\left.60^{\circ} \mathrm{C}\right)$, and content of organic matter $\left(1.5\right.$ to $2 \mathrm{~h}$ at $\left.500^{\circ} \mathrm{C}\right)$ were measured on 20 individuals from each pearl net. The remaining mussels from each net were pooled and treated together.

To compensate for wind-and tide-induced changes in the water level in Roskilde Fjord the enclosures connected to the sediment were constructed with a buoyancy and weight system similar to that described by Landers (1979) (Fig. 1). This construction allowed the enclosures to withstand a change in water level of about $2 \mathrm{~m}$ without damage. The maximal change in the water level was about $1 \mathrm{~m}$ during the end of June, and, in fact, no damage occurred to the system. Two of the enclosures were damaged for other reasons during September, and data from these were omitted.

Pigment and phytoplankton analyses. Water samples for chlorophyll analyses were taken every 2 to $4 \mathrm{~d}$ with a 31 plastic sampler from 3 depths in the enclosures $(0.5,1.5$, and $3 \mathrm{~m}$ ) and mixed prior to analyses. Chlorophyll a was extracted in $96 \%$ ethanol for $20 \mathrm{~h}$ without homogenization of the $25 \mathrm{~mm}$ filters (Whatman GF/C) and the pigment extracts were measured fluorometrically (Aminco 2000) without correction for degradation products. To calculate absolute values, fluorometric emission values were calibrated to absorbance readings from a spectrophotometer (Beckman 240) using chlorophyll extracts from larger volumes of water from the same depths. A specific absorption coefficient of $83.4 \mathrm{I} \mathrm{g}^{-1} \mathrm{~cm}^{-1}$ for chlorophyll $a$ in ethanol was used (Wintermans \& De Motts 1965).

Picoautotrophs (1 to $2 \mu \mathrm{m}$ ) were enumerated by epifluorescence microscopy (1250x magnification) and green excitation by counting autofluorescing cells using proflavine dye (Haas 1982). The rest of the phytoplankton were counted, classified and measured using 
an inverted microscope. Samples were taken at the start and end of each period and fixed with Lugol's solution.

Data treatment. All manipulations were carried out in duplicate. The effects of the various manipulations were calculated as a percentage of their respective controls for each period (Table 1). The data were

Table 1. Treatments and their respective controls. Mussels $(\mathrm{M})$, nutrients $(N)$, fish $(F)$, sediment contact $(S)$, control $(C)$. All treatments were duplicated

\begin{tabular}{|llllll}
\hline \multirow{2}{*}{ Treatment } & & \multicolumn{4}{c}{ Enclosures } \\
\hline \multirow{2}{*}{ Mussels } & Samples: & M & MN & MF & MFN \\
& Controls: & C & N & F & FN \\
& Samples: & F & FN & FM & FMN \\
& Controls: & C & N & M & MN \\
Nutrients & Samples: & N & NF & NM & NFM \\
& Controls: & C & F & M & FM \\
Sediment & Samples: & S & SN & SN & SFN \\
& Controls: & C & N & F & FN \\
& & & & & \\
\hline
\end{tabular}

divided into 4 groups according to temperature. Thus, material obtained during April was divided into a group of data with temperatures of 0 to $4.5^{\circ} \mathrm{C}$ and a group with temperatures 6 to $9^{\circ} \mathrm{C}$.

Data treatment included calculation of the relative deviation on the chlorophyll values, using a plot of the deviation from the mean of duplicate enclosures vs the respective means of duplicates. The calculated relative deviation was $18 \%$ (Bjørnsen et al. unpubl.). The standard error of the effects of the various manipulations was calculated from the formula:

$$
\frac{C^{\frac{X}{y}}}{\frac{x}{y}}=\sqrt{\left(\frac{C_{\zeta}(x)}{x}\right)^{2}+\left(\frac{C_{S}(y)}{y}\right)^{2}}
$$

where $x$ and $y=$ mean values of sample and control; and $\mathcal{C}_{1}(x, y)$ are the deviations from the mean values obtained from the relative deviations.

Phytoplankton $\mathrm{CO}_{2}$ assimilation. A relative measure of phytoplankton $\mathrm{CO}_{2}$ assimilation was obtained from the enclosures with added mussels. In situ incubations $(25 \mathrm{ml})$ with $1 \mu \mathrm{Ci} \mathrm{NaH}{ }^{14} \mathrm{CO}_{3}$ added were carried out for $2 \mathrm{~h}$ at the surface and at the $30 \%$ light depth between 10:00 and 12:00 h. Incubations were stopped by adding $\mathrm{HgCl}_{2}(5 \mathrm{ppm})$. Unassimilated ${ }^{14} \mathrm{C}$ was removed by acidification to $\mathrm{pH} 3$ and bubbling with air for 30 min. Samples were shaken with $10 \mathrm{ml}$ Dynagel (Beckman) and radioassayed by LSC. Time zero incubations were subtracted as blanks. Concentration of $\mathrm{CO}_{2}$ was determined by infrared gas analysis. The average $\mathrm{CO}_{2}$ assimilation ( $\mu \mathrm{g} \mathrm{Cl}^{-1} \mathrm{~h}^{-1}$ ) was calculated as the mean of the 2 samples.

\section{RESULTS}

Phytoplankton chlorophyll content in the enclosures ranged over 2 orders of magnitude during the 3 experimental periods (Fig. 2). During June/July and September, pronounced changes in chlorophyll concentrations were observed in response to manipulations with nutrients, mussels or fish (Fig. 2 B, C). Mean initial chlorophyll concentration decreased from $29 \mu \mathrm{g} \mathrm{J}^{-1}$ in April to 13 and $3 \mu \mathrm{g} \mathrm{l}^{-1}$ in June and September, respectively. At the end of the September experiment, a significant decrease in chlorophyll concentration was found in most of the enclosures, presumably due to enhanced sedimentation during a period with extremely calm wind conditions.

Mussels permitted increases in the number of unicellular cyanobacteria (Fig. 3a). At the start of the experiment the number of cyanobacteria was $0.4 \times 10^{5}$ $\mathrm{ml}^{-1}(\mathrm{SD}=0.09)$, corresponding to $6.5 \%$ of the total phytoplankton volume ( $\mathrm{SD}=1.7 \%$ ). At the end of the experiment the number of cyanobacteria was 3.9 to $6.2 \times 10^{5} \mathrm{ml}^{-1}$ in the enclosures with mussels and 0.2 to $4.8 \times 10^{5} \mathrm{mi}^{-1}$ in controls, and cyanobacteria constituted 70 to $93 \%(\bar{x}=82 \%)$ of the total phytoplankton volume in enclosures with added mussels compared to 4 to $20 \%(\bar{x}=11 \%)$ in the controls (Fig. 3b).

A negligible number $\left(<100 \mathrm{ml}^{-1}\right.$, corresponding to less than $0.001 \%$ of the total phytoplankton volume) of these small cells were found in September and April (data not shown) and no measurable differences in cell number were found between the enclosures.

Lower rates of $\mathrm{CO}_{2}$ assimilation were found during June than during September (Table 2), in spite of the fact that the insolation rate was twice as high during June than in September (Fig. 4). Nitrogen apparently controlled $\mathrm{CO}_{2}$ assimilation during June, as the addition of inorganic nitrogen raised $\mathrm{CO}_{2}$ assimilation a factor of 5 to 6 compared to assimilation levels in controls without added nutrients (Table 2). Nitrogen additions in combination with additions of mussels resulted in minor changes in phytoplankton $\mathrm{CO}_{2}$ assimilation during April and September (Table 2).

Temperatures ranged from 0 to $9^{\circ} \mathrm{C}$ in April, from 17 to $22^{\circ}$ in June/July and from 11 to $13^{\circ} \mathrm{C}$ in September (Fig. 4). Insolation was almost the same in April and September, and less than half the rates measured in June. Salinity ranged from 12 to $16 \%$ (Fig. 4).

\section{Effects of mussels}

During the first April period $\left(0\right.$ to $\left.4.5^{\circ} \mathrm{C}\right)$, no effects of mussels on chlorophyll levels were found $(100 \%$ of the respective controls). During the second April period 
Fig. 2. Examples of daily changes in phytoplankton chlorophyll content from enclosures during (A) April, (B) June/July, and (C) September 1986. Bars represent total variation from duplicate enclosures. $(\square)$ Controls; $(\bullet)$ added nutrients; $(x)$ added fish; $(0)$ added mussels
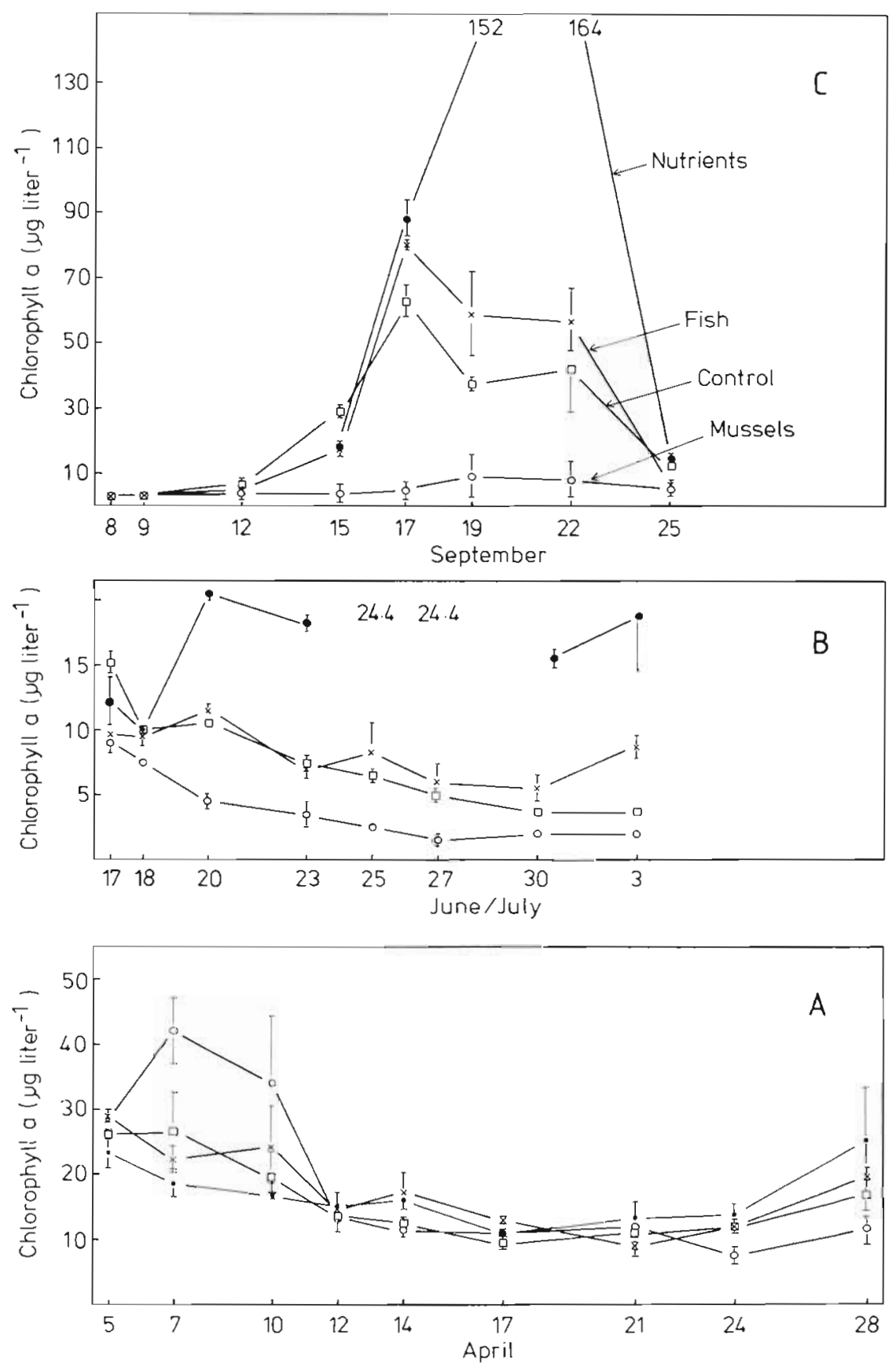

$\left(6\right.$ to $\left.9^{\circ} \mathrm{C}\right)$ and the June/July period $\left(17\right.$ to $\left.22^{\circ} \mathrm{C}\right)$, the addition of mussels reduced chlorophyll concentrations to $54 \%$ and $59 \%$ of controls (Fig. 5). More dramatically, only $10 \%$ (average for the 4 treatments) of the phytoplankton biomass remained in the enclosures with added mussels during the September period (temperatures 11 to $13^{\circ} \mathrm{C}$ ). No significant differences $(p>0.05)$ on chlorophyll were found between the relative effects of mussels added alone (M) or together with nutrients (MN) or fish (MF) or both (MNF) in relation to controls (Fig. 5).

\section{Mussel growth}

Results obtained from individual pearl nets suggested faster growth of mussels situated near the surface of the enclosures. Nevertheless, results from the 3 depths were pooled. Following this, each bar in Fig. 6 represents 1044 to 1137 individuals corresponding to an average of $690 \mathrm{~g}$ wet wt for each manipulation at the beginning of the spring and summer experiments, and 665 to 695 specimens with an average wet wt of $474 \mathrm{~g}$ at the beginning of the September period. 


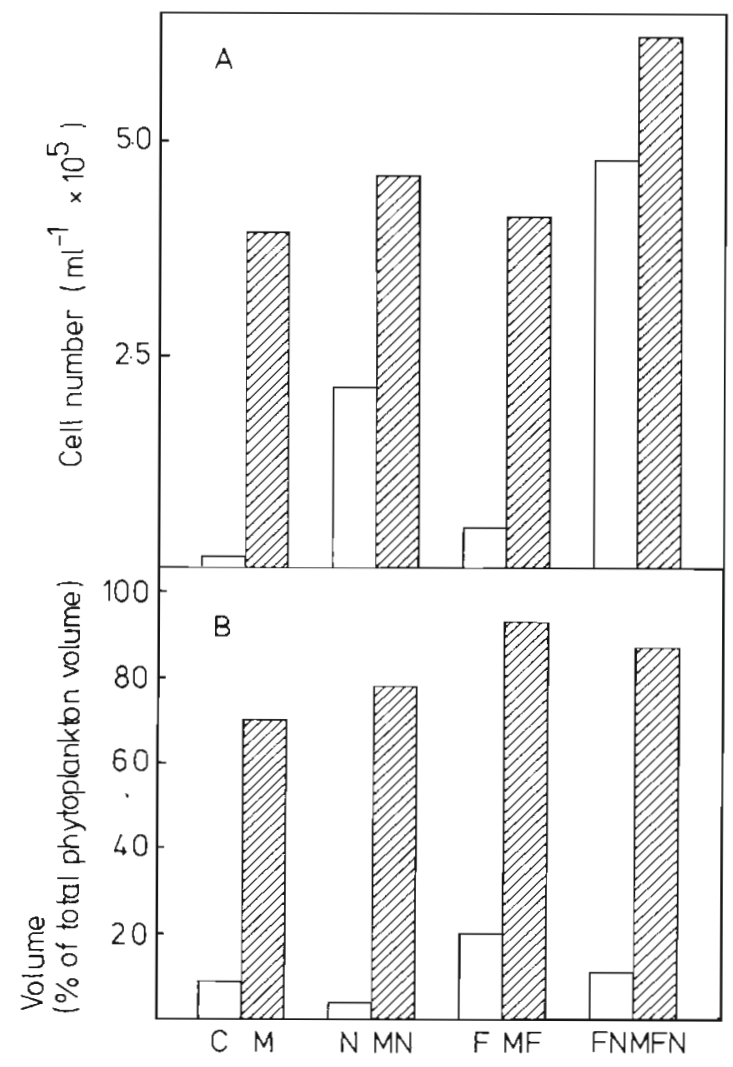

Fig. 3. (A) Numbers of autotrophic picoplankton (1 to $2 \mu \mathrm{m}$ ) and (B) cell volume (\% of phytoplankton volume) in enclosures with and without addition of mussels in June/July. $C$ : control $; M, F, N$ : additions of mussels, fish and nutrients, respectively

Daily growth of mussels was calculated as changes in dry weight, organic weight and length (Fig. 6). Because the mussels used in September were longer (unpubl. data), the increase in dry weight and organic weight relative to increase in shell length was greater than in June/July and much greater than in April.

During April, daily shell growth in enclosures ranged
Table 2. Relative average phytoplankton $\mathrm{CO}_{2}$ assimilation ( $\mu \mathrm{C} \mathrm{Cl}^{-1} \mathrm{~h}^{-1}$ ) in enclosures to which mussels were added during the experimental periods. M: mussels, $N$ : nutrients, F: fish

\begin{tabular}{|lcccc|}
\hline & 12-21 Apr & 24-28 Apr & 18 Jun-3 Jul & 12-25 Sep \\
\hline M & 7.9 & 6.7 & 3.6 & 10.5 \\
MN & 7.7 & 3.2 & 20.6 & 7.0 \\
MF & 5.1 & 6.1 & 5.5 & 8.5 \\
MFN & 6.1 & 5.5 & 26.9 & 10.6 \\
\hline
\end{tabular}

from $0.065 \mathrm{~mm}$ (M) to $0.075 \mathrm{~mm}$ (MNF), whereas corresponding changes in dry weight and organic weight ranged from $1.01 \mathrm{mg} \mathrm{d} \mathrm{d}^{-1}(\mathrm{MF})$ to $1.78 \mathrm{mg} \mathrm{d}^{-1}$ $(\mathrm{MNF})$, and from $0.10 \mathrm{mg} \mathrm{d}^{-1}(\mathrm{MF})$ to $0.52 \mathrm{mg} \mathrm{d}^{-1}$ (MNF), respectively.

During April and June/July mussels grew significantly better in pearl nets in the open fjord than inside the enclosures. During September, however, growth rates of mussels from the fjord were similar to rates measured inside the enclosures.

The manipulation effects on growth rates of mussels were most pronounced in terms of shell length. Growth rates expressed in units of dry weight or organic weight increased with increase in shell length, but there was no isometric relationship between increases in length and in organic weight as described by Nielsen (1985). It should be noted that mussels used in April and June/ July were in better condition than those sampled in September (Table 3). During June, a decrease in organic content ( $\%$ of dry weight) was observed (Table 3 ).

\section{Effects of fish}

Effects of fish were less easy to identify than effects of mussels. During the 2 April periods, chlorophyll concentrations in enclosures with added fish were 83 to $115 \%(\bar{x}=98 \%)$ of controls; during June 109 to $141 \%$ $(\overline{\mathrm{x}}=121 \%)$ and during September 109 to $163 \%$ (with

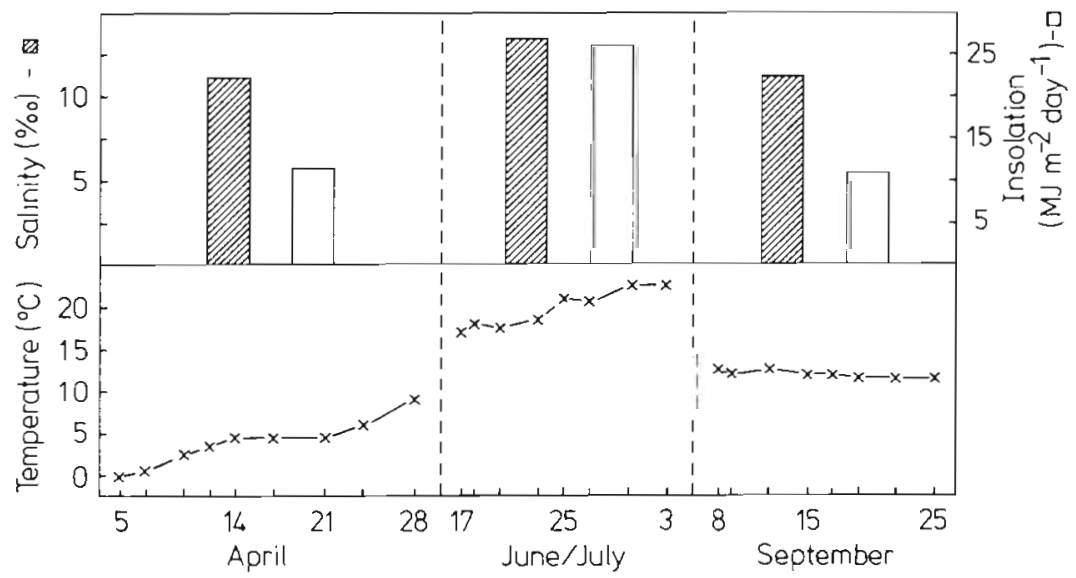

Fig. 4. Temperature, salinity and mean insolation rate during the 3 experimental periods 
Fig. 5. Effects of the addition of mussels (M), fish $(\mathrm{F})$ and nutrients $(\mathrm{N})(\%$ of controls) on the phytoplankton biomass during April, June/July, and September 1986. Bars represent SE, calculated according to the procedure described in text

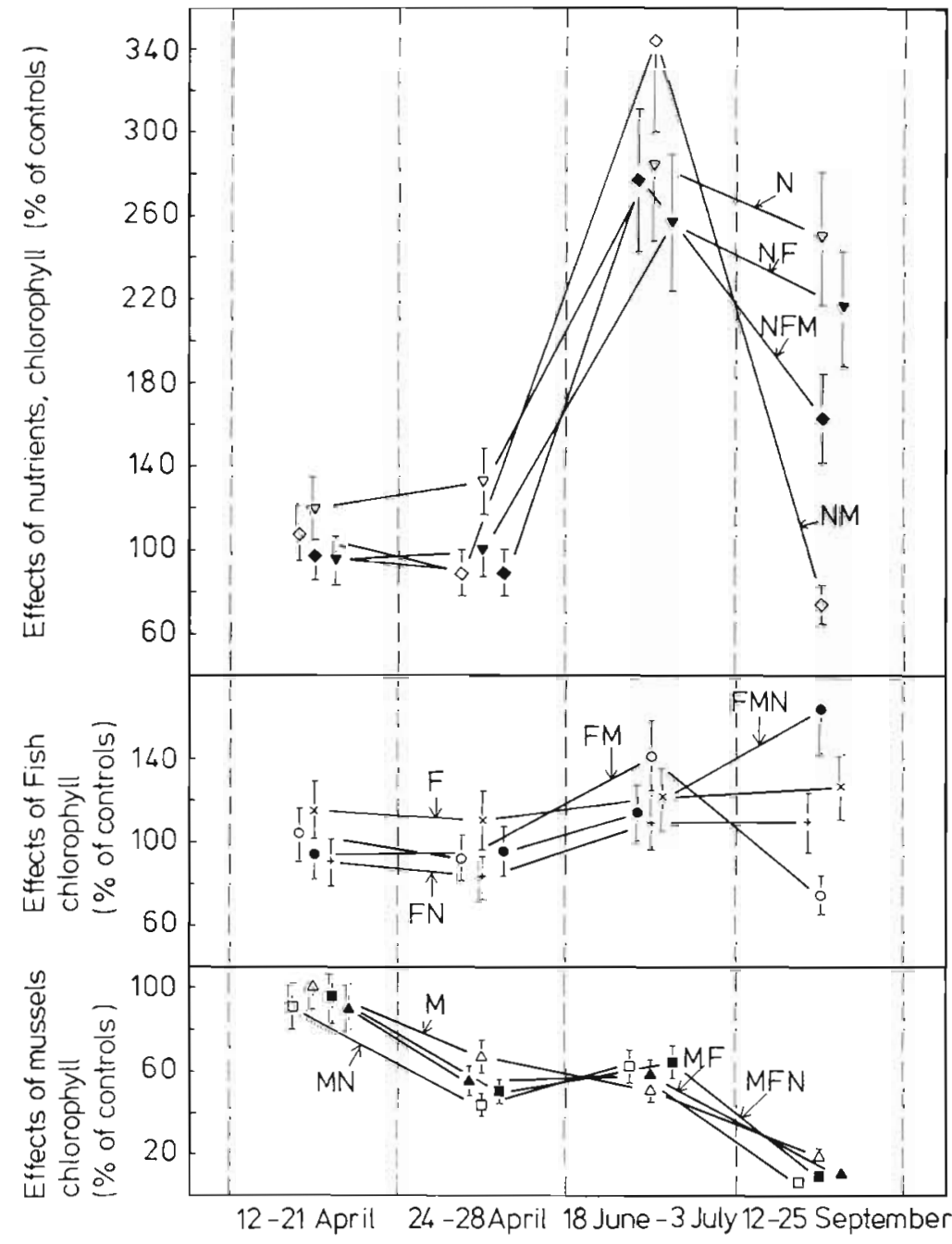

Fig. 6. Daily growth of mussels in enclosures manipulated by addition of nutrients $(\mathrm{N})$ and fish $(\mathrm{F})$, and in the open fjord $(\mathrm{M}=$ mussels). Open columns: increase in dry weight; cross-hatched columns: increase in organic weight; solid columns: increase in length

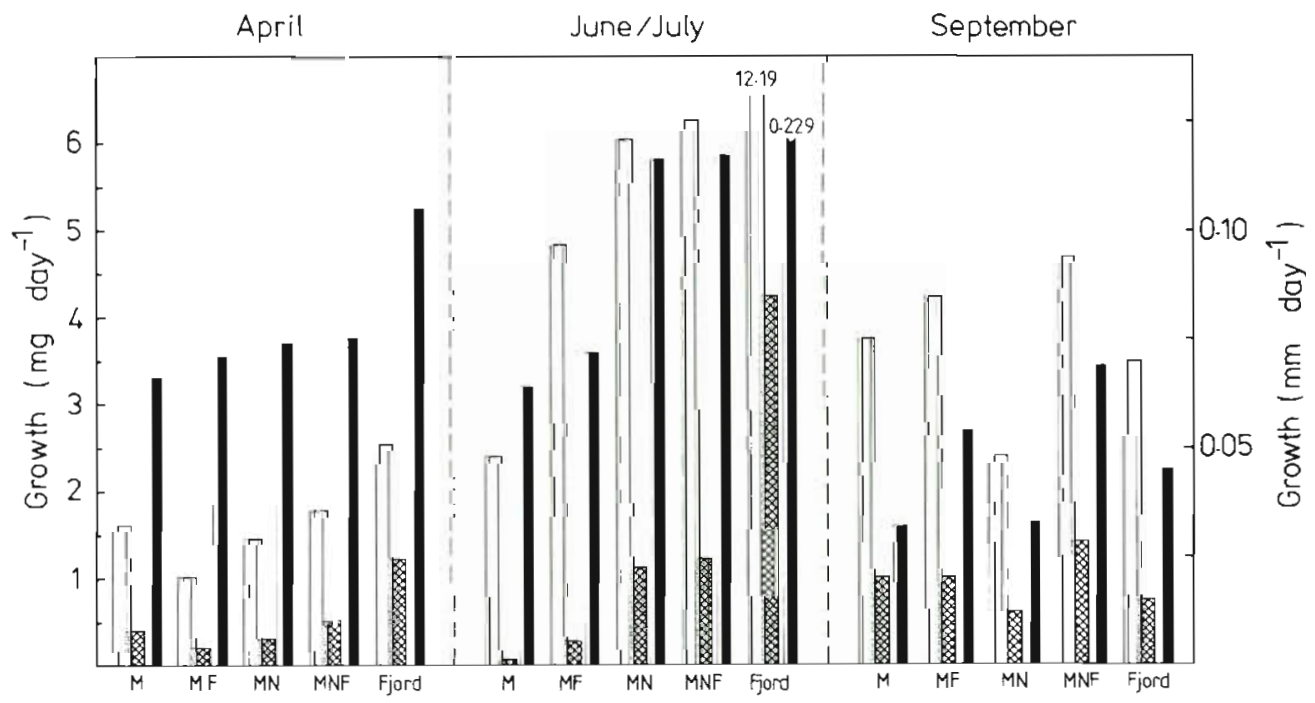


Table 3. Organic weight as \% of dry weight during April, June/July and September experiments in the open fjord and in enclosures manipulated by addition of nutrients $(N)$ and $(F)$. (M: mussels). Values in brackets represent $95 \% \mathrm{CL}$

\begin{tabular}{|llccc|}
\hline Month & Manipulation & $\begin{array}{c}\text { Organic content } \\
\text { at Day } 0 \\
(\%)\end{array}$ & $\begin{array}{c}\text { Organic content at end of } \\
\text { growth period } \\
(\%)\end{array}$ & $\begin{array}{c}\text { Change in organic } \\
\text { content } \\
(\%)\end{array}$ \\
\hline Apr & M, MF, MN, MNF & $19.99(0.38)$ & $20.16 \pm 0.25$ & $0.17 \pm 0.56$ \\
Apr & Fjord & $19.99(0.38)$ & $24.72 \pm 0.48$ & $4.75 \pm 0.61$ \\
Jun/Jul & M, MF & $21.79(0.35)$ & $19.00 \pm 0.27$ & $-2.79 \pm 0.44$ \\
Jun/Jul & M, MNF & $21.79(0.35)$ & $21.09 \pm 0.27$ & $-0.70 \pm 0.44$ \\
Jun/Jul & Fjord & $21.79(0.35)$ & $27.03 \pm 0.47$ & $5.24 \pm 0.59$ \\
Sep & M, MF, MN, MNF & $14.08(0.23)$ & $15.76 \pm 0.19$ & $1.68 \pm 0.30$ \\
Sep & Fjord & $14.08(0.23)$ & $15.20 \pm 0.39$ & $1.12 \pm 0.45$ \\
\hline
\end{tabular}

the exclusion of 1 low value from the enclosures with added mussels and fish [ $74 \%]$ ). The average for the entire September material was $118 \%$ (Fig. 5).

\section{Addition of nutrients}

Addition of nutrients to the enclosures in April did not alter chlorophyll concentrations significantly from controls. In June, chlorophyll in the nutrient-enriched enclosures reached 257 to $344 \%(\bar{x}=290 \%)$ of respective controls and in September from 163 to $250 \%$ of controls. Only in enclosures where both mussels and nutrients were added was the average chlorophyll content lower (74\% in September) than in the controls (Fig. 5).

\section{Effects of sediment contact}

The sediment acted primarily as a nutrient source. The chlorophyll concentrations in enclosures with contact to the sediment were higher than in the controls without nutrients during the June/July period (Fig. 7) and similar to those with added nutrients. During the first April period $\left(0\right.$ to $\left.4.5^{\circ} \mathrm{C}\right)$, however, chlorophyll levels were almost the same in all enclosures, irrespective of the manipulations carried out. During the second April period $\left(6\right.$ to $9^{\circ} \mathrm{C}$ ), lower chlorophyll values were recorded in all enclosures in contact with the sediment than in controls, due to activity of benthic suspension feeders (Fig. 5). The same pattern was observed during September.

\section{DISCUSSION}

The experimental approach enabled us to evaluate the effects of the addition of suspension-feeding

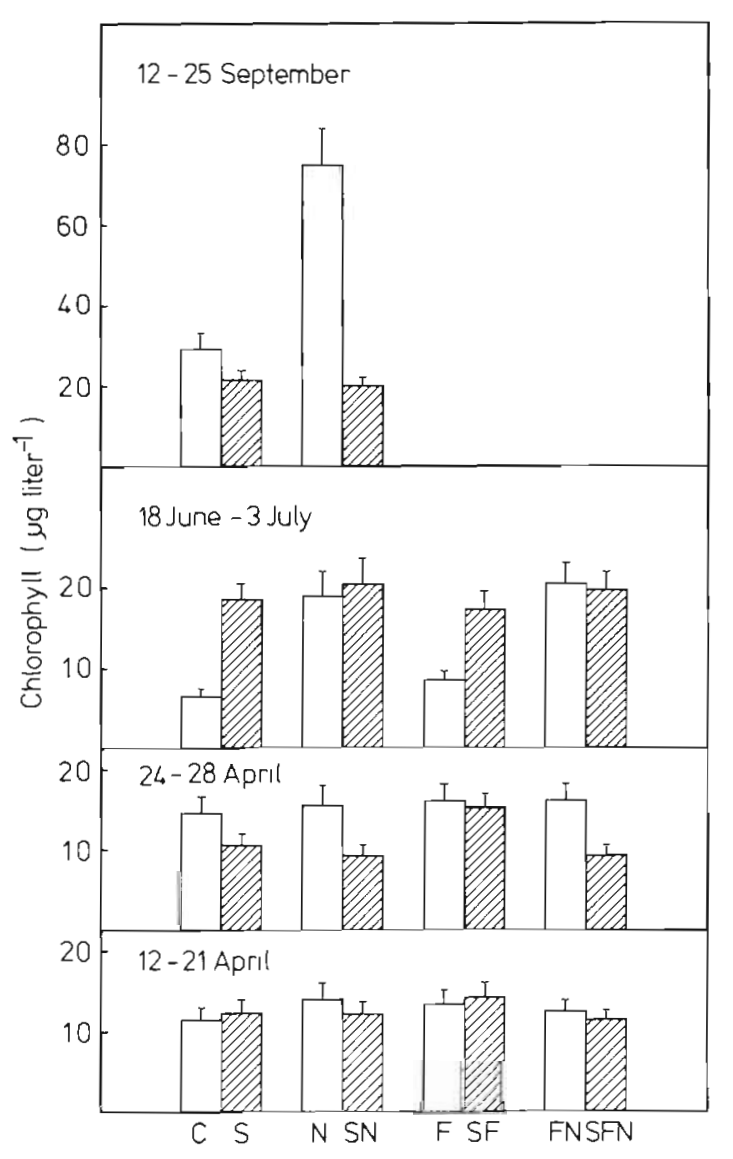

Fig. 7. Effects of sediment contact (S) on chlorophyll content in enclosures during April, June/July, and September 1986. Bars represent SE calculated as in Fig. 2

mussels, planktivorous fish and nutrients on the quantitative development of phytoplankton in experimental enclosures. As expected, each variable (except fish addition) caused considerable changes in the phytoplankton populations. However, these effects varied depending on the season. 


\section{Effects of mussel addition}

The primary effect of the presence of mussels was a reduction in chlorophyll levels. The seasonal changes in the effects of mussels can be explained as consequences of (1) higher phytoplankton $\mathrm{CO}_{2}$ assimilation rates during June, (2) higher clearance rates of the mussels during September, or (3) changes in the phytoplankton size distribution.

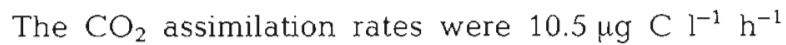
during September, i.e. more than twice the rates found during June/July. The low rates during June/July were probably caused by inorganic nitrogen limitation. Additions of nitrate during this period raised $\mathrm{CO}_{2}$ assimilation by at least a factor of 5 (Table 2). During September, nutrient additions did not change the average $\mathrm{CO}_{2}$ assimilation compared with rates found in controls (Table 2). It should be stated that even though the average values presented in Table 2 did not suggest nitrogen limitation of the $\mathrm{CO}_{2}$ assimilation, results from 2 dates gave higher $\mathrm{CO}_{2}$ assimilation rates in enclosures with added nutrients. Thus, nitrogen also limited $\mathrm{CO}_{2}$ assimilation in September; however, the extent of this was much smaller than in June/July.

Concerning altered clearance rates by mussels, there are no reports demonstrating that mussels welladapted to the environment should have lower clearance rates at 20 to $22^{\circ} \mathrm{C}$ than at 11 to $12^{\circ} \mathrm{C}$. On the contrary, Shulte (1975) reported that optimum filtration rates for Mytilus edulis covered a broad range from 15 to $25^{\circ} \mathrm{C}$. Above $25^{\circ} \mathrm{C}$ there was a dramatic cessation of the filtration rate.

Thus, the size distribution of the phytoplankton biomass seems to be of vital importance for the extent to which Mytilus edulis can regulate phytoplankton biomass. Picoplankton cells were found in large numbers during June, particularly in enclosures with added mussels. According to Møhlenberg \& Riisgård (1978), the particle retention efficiency of $M$. edulis drops from $100 \%$ for particles $>4 \mu \mathrm{m}$ to about $50 \%$ for $1 \mu \mathrm{m}$ particles. Thus, if we assume that the mussels had the same filtration rates in June/July and September, the effect of mussels on phytoplankton biomass would be less pronounced in June/July, since $82 \%$ of the phytoplankton volume was composed of 1 to $2 \mu \mathrm{m}$ cells. On the other hand, picoplankton comprised $<0.001 \%$ of the phytoplankton volume during September when $M$. edulis removed $90 \%$ of the phytoplankton biomass. The occurrence of cyanobacteria was apparently favored during periods with nitrogen depletion. Nitrogen depletion was only observed during June/July, and even though nitrate was added we cannot rule out the possibility that nitrogen also limited growth of phytoplankton in the enclosures to which nitrate was added, since concentrations of inorganic nitrogen occa- sionally went below $5 \mu \mathrm{g} \mathrm{l^{-1 }}$ (unpubl.). However, high insolation rates and high temperatures during the June/ July period could also have contributed to the abundance of picoplankton. When nitrogen did not limit phytoplankton $\mathrm{CO}_{2}$ fixation (during April and September), cyanobacteria constituted a maximum of $0.001 \%$ of the phytoplankton volume. Stockner \& Antia (1986) discussed the possibility that Synechococcus spp. may fix atmospheric nitrogen. However, in view of the limited amount of published data, no generalizations were made. Benthic suspension feeders can reduce the effects of nutrients in marine coastal areas (Cloern 1982, Officer et al. 1982) and act as a stabilizing factor in the ecosystem (Kautsky 1982). The addition of the M. edulis populations even reduced the chlorophyll levels to below those in the controls in the enclosures to which nutrients were added (Fig. 5). There was no significant difference between treatments in the development of chlorophyll in the experimental enclosures with added mussels $(p>0.05)$.

\section{Mussel growth}

During the 3 experiments, effects of the manipulations were also seen on the growth rate of mussels. Generally, low growth rates were found in enclosures containing mussels alone (Fig. 6). Addition of planktivorous fish increased phytoplankton available for the mussels, presumably because of reduced competition from zooplankton, and the mussels tended to grow better in these enclosures. Also the addition of nutrients increased mussel growth rates. Addition of fish and nutrients further increased mussel growth, although not additively (Fig. 6). Effects of the nutrient additions on Mytilus edulis growth were most pronounced and only significant during the June/July experiment, presumably because nitrogen depleted the growth of the phytoplankton.

A positive correlation between fisheries yields and phytoplankton primary production has been reported (Nixon \& Pilson 1983). The changes in growth rates of mussels added to our enclosures during the summer experiment support the idea that increased nutrient loads also increase secondary production of benthic suspension feeders. This effect was for unknown reasons not observed during September.

During June the decrease in organic content was probably caused by food limitation at the end of the experiment (Table 3). This also explains the relatively low increase in organic weight observed during the June experiment.

The mussels in our experiment were suspended above the sediment in a limited volume of water. An important question is how these suspended mussels 
grew in relation to growth of the natural population of suspension feeders. Kautsky (1982) compared growth of mussels $1 \mathrm{~m}$ above a mussel bed with mussels at the bottom, and found a significantly better growth of the suspended mussels. The difference between growth at the bottom and the mussels in suspension is explained by normal food limitation of benthic suspension feeders (Fréchette \& Bourget 1985a). Suspension of mussels in the present experiment may have enhanced growth and thus had larger effects on the environment compared to a 'natural' mussel population.

The growth measured in the enclosures during our experiments falls within the range measured in 'natural' mussel populations in 6 other Danish fjords (0.04 to $0.13 \mathrm{~mm} \mathrm{~d}^{-1}$, calculated from Birklund (1975) and Theisen (1975) assuming a growth period of $6 \mathrm{mo}$ ), justifying that the effects seen in these experiments are representative of events in Roskilde Fjord.

The high growth rates of mussels incubated in the open fjord during April and June/July (Fig. 6) were probably a result of better mixing of the water and thereby a better food supply, and should be considered as potential growth of caged mussels at the experimental location. In September, growth rates of mussels suspended in the open fjord were similar to growth rates of mussels inside the enclosures. This was probably due to calm wind conditions and reduced mixing of the water.

\section{Effects of fish addition}

Addition of fish increased average chlorophyll concentrations by $20 \%$ more than in the relevant controls under temperature regimes of 11 to $22^{\circ} \mathrm{C}$ (June/July and September). The fish removed about $90 \%$ of the zooplankton biomass in enclosures during June/July and September and about $50 \%$ during April (Horsted et al. 1988; companion article). We assume that the possible increased availability of nutrients from the fish to the phytoplankton was negligible; the actual concentrations of inorganic nitrogen and phosphorus did not increase in the enclosures containing fish (unpubl.).

\section{Effects of nutrient additions}

Additions of nutrients increased chlorophyll concentrations by an average value of $256 \%$ during June/July and September when inorganic nitrogen controls phytoplankton primary production in Roskilde Fjord (Borum 1985). This increase should be considered a minimum value, since low concentrations of inorganic nitrogen were recorded despite the nutrient additions (unpubl.). Even though the additions delayed nutrient depletion, it was not completely avoided. No effects of the addition of nutrients were recorded during the first April period, due to the decaying diatom population and the low temperatures.

\section{Effects of sediment contact}

Effects of contact with the sediment are 2 -fold. Sediments can act as a nutrient source and, thereby, increase phytoplankton biomass. Benthic suspension feeders in the sediment feed upon phytoplankton and, thereby, can reduce phytoplankton biomass. During June, the sediment acted mainly as a nutrient source. Suspension feeders were present in the sediment. However, the construction which connected the enclosures to the sediment probably reduced water movement so much that oxygen depletion occurred. Even though oxygen concentrations did not go below $5 \mathrm{mg} \mathrm{I}^{-1}$ about $0.5 \mathrm{~m}$ above the sediment surface (unpubl.), oxygen depletion just above the surface could reduce the clearance rates of the mussels. During the second April period (24 to 28 April) and the September period, chlorophyll levels in enclosures connected to the sediment were lower than those in controls, presumably because of increased effects of benthic suspension feeders as demonstrated in the enclosures with added mussels (Fig. 5). During the first April period (12 to 21 April), no significant $(p>0.05)$ differences were found between the chlorophyll content in enclosures with and without sediment contact. The reasons for these small variations are not clear. However, the decaying diatom populations were not regulated by nitrate or phosphate. Moreover, low temperatures $\left(0\right.$ to $4.5^{\circ} \mathrm{C}$ ) reduce filtration rates by Mytilus edulis to below $20 \%$ of maximal rates (Schulte 1975) and in addition prevent a successional development of other groups of phytoplankton.

In our analysis of chlorophyll changes during different periods, results from April were divided into 2 groups based on changes in temperature. This reduced the number of days during which effects on the chlorophyll levels were observed in the 2 groups of data (Fig. 5). Alternatively, all data from the April period could have been treated together. We believe that the comparable results on mussels inside the enclosures and those on mussels in enclosures with contact to the sediment (Fig. 7) during the second April period justify the division of data.

In conclusion, the phytoplankton biomass in the enclosures was controlled by different factors during the year. Zooplankton played a minor role in most combinations. However, interactions between nutrient input, phytoplankton size distribution and the physiological state of the mussels was of vital importance. 
The occurrence of picoplankton appears to be important for the size of the phytoplankton biomass, since Mytilus edulis as well as other benthic suspension feeders have low retention efficiencies for picoplankton.

As an example of the importance of the factors controlling the phytoplankton biomass, chlorophyll concentrations could theoretically change by a factor of 25 from $10 \%$ of the controls to at least $256 \%$ of the controls, if we assume that mussels stopped their activity during September due to, for example, oxygen depletion at the sediment surface.

Acknowledgements. We thank J. Borum and C. A. Oviatt for valuable comments and $K$. Richardson for suggestions and linguistic improvements. We also thank B. Kruse for help with the nutrient analyses and J. Birkland for supporting us with the Japanese pearl nets. Technical assistance was carried out by W. Martinsen, A. Klenow, P. Simonsen, F. Heegaard, and F. Pedersen. This work was supported by The Danish Environmental Protection Agency (NPO 4.6) and by The Danish Natural Science Research Council (J. no. 11-5573).

\section{LITERATURE CITED}

Birklund, J. (1975). En økologisk undersøgelse af macrofaunaen i Holbæk Fjord. Ph. O. thesis unpubl., Water Quality lnstitute, ATV (Danish)

Borum, J. (1983). The quantitative role of macrophytes, epiphytes and phytoplankton under different nutrient conditions in Roskilde Fjord, Denmark. In: Proc. Int. Symp. Aquatic Macrophytes (Sept. 1983), Nijmegen, The Netherlands, p. $35-40$

Borum, J. (1985). Development of epiphytic communities on eelgrass (Zostera marina) along a nutrient gradient in a Danish estuary. Mar. Biol. 87: 211-218

Boynton, W. R., Kemp, W. M., Keefe, C. W. (1982). A comparative analysis of nutrients and other factors influencing estuarine phytoplankton production. In: Kennedy, V S. (ed.) Estuarine comparisons. Academic Press, New York, p. 69-90

Cattaneo, A., Kalff, J. (1980). The relative contribution of aquatic macrophytes and their epiphytes to the production of macrophyte beds. Limnol. Oceanogr. 25: 280-289

Cloern, J. E. (1982). Does the benthos control phytoplankton biomass in South San Francisco Bay? Mar. Ecol. Prog. Ser. 9: $191-202$

Fréchette, M., Bourget, E. (1985a). Energy flow between the pelagic and benthic zones: factors controlling particulate organic matter available to an intertidal mussel bed. Can. J. Fish. Aquat. Sci. 42: 1158-1165

Fréchette, M., Bourget, E. (1985b). Food-limited growth of
Mytilus edulis $\mathrm{L}$. in relation to the benthic boundary layer. Can. J. Fish. Aquat. Sci. 42: 1166-1170

Gislason, H. (1980). Fødekæden i Roskilde Fjord. Fisk og Hav 1980: 23-28. (Danish)

Haas, L. W. (1982). Improved epifluorescence microscopy for observing planktonic microorganisms. Ann. Inst. Oceanogr. 58: 261-266

Jørgensen, C. B. (1976). Growth efficiencies and factors controlling size in some mytilid bivalves, especially Mytilus edulis L. Review and interpretation. Ophelia 15: 175-192

Jørgensen, C. B. (1984). Effect of grazing: metazoan suspension feeders. In: Hobbie, J. E., Williams, P. J. LeB. (eds.) Heterotrophic activity in the sea. Plenum Press, New York, p. $445-464$

Kautsky, N. (1981). On the role of the blue mussel, Mytilus edulis L. in the Baltic ecosystem. Rap. Dep. Zoology, Askö Lab., Univ. of Stockholm, Sweden, p. 23

Kautsky, N. (1982). Growth and size structure in a Baltic Mytilus edulis population. Mar. Biol. 68: 117-133

Landers, D. H. (1979). A durable, reusable enclosure system that compensates for changing water levels. Limnol. Oceanogr. 24: 991-994

Møhlenberg, F., Riisgård, H. U. (1978). Efficiency of particle retention in 13 species of suspension feeding bivalves. Ophelia 17: $239-246$

Møhlenberg, F., Riisgård, H. U. (1979). Filtration rate, using a new indirect technique, in thirteen species of suspensionfeeding bivalves. Mar Biol. 54: 143-147

Nielsen, M. V. (1985). Increase in shell length as a measure of production and ingestion of Mytilus edulis L. J. exp. mar. Biol. Ecol. 88: 101-108

Nixon, S. W., Pilson, M. E. Q. (1983). Nitrogen in estuarine and coastal marine environments. In: Carpenter, E. J., Capone, D. G. (eds.) Nitrogen in the marine environment. Academic Press, New York, p. 565-684

Officer, C. B., Smayda, T J., Mann, R. (1982). Benthic filter feeding: a natural eutrophication control. Mar. Ecol. Prog. Ser. 9: 203-210

Riisgård, H. U., Poulsen, E. (1981). Growth of Mytilus edulis in net bags tranferred to different locations in an eutrophicated Danish Fjord. Mar. Pollut. Bull. 12: 272-276

Shulte, E. H. (1975). Influence of algal concentration and temperature on the filtration rate of Mytilus edulis. Mar. Biol. 30: 331-341

Stockner, J. G., Antia, N. J. (1986). Algal picoplankton from marine and freshwater ecosystems: a multidisciplinary perspective. Can. J. Fish. Aquat. Sci. 43: 2462-2503

Theisen, B. F. (1975). Growth parameters of Mytilus edulis L. (Bivalvia) estimated from tagging data. Meddr Danm. Fisk.- og Havunders. 7: 99-109

Winter, J. E. (1973). The filtration rate of Mytilus edulis and its dependence on algal concentration, measured by a continuous automatic recording apparatus. Mar. Biol. 22: $317-328$

Wintermans, J. F. G. M., De Mots, A. (1965). Spectrophotometric characteristics of chlorophylls $a$ and $b$ and their pheophytins in ethanol. Biochem. Biophys. Acta. 109: 448-453 